\title{
Prostate Carcinoma Metastatic in Lymph Node
}

National Cancer Institute

\section{Source}

National Cancer Institute. Prostate Carcinoma Metastatic in Lymph Node. NCI

Thesaurus. Code C161587.

A carcinoma that arises from the prostate gland and has spread to the lymph nodes. 